\title{
Christian Mysticism: A Meta-Theoretical Approach - Part III
}

\author{
Herman J. Pietersen \\ University of Limpopo, Turfloop Campus 0727, Republic of South Africa \\ herman.pietersen@ul.ac.za
}

\section{Doi:10.5901/mjss.2014.v5n16p589}

\section{Abstract}

In this paper the work of three outstanding representatives of poetical (type III) mysticism is briefly considered. Although exemplars of speculative and systematic mysticism also engage in quasi-poetical prose in their formulations and sermons, they do not do so in the same highly expressive, direct and emotionally intense manner that is typical of the type III mystic. For this reason Richard Rolle, Henry Suso and Madame Guyon were selected as exemplars of poetical mysticism, and discussed in section 1. The poetically-inclined Christian mystic is not interested in either metaphysical speculation, or in Aristotelian analyses of the nature and elements of the mystic life (see paper 2). It is a deeply personal matter of the heart, of recounting one's experiences on the mystic journey and singing the praises of the divine, rather than merely a matter of the intellect. In section 2 the pragmatic (type IV) theologies of John Tauler, the anonymously authored Cloud of Unknowing, and the work of the Spanish mystic, Miguel de Molinos are reviewed. Their mystical writings and activities have a much stronger practical focus and action-orientation (in the subjectivist-empyrean mode), compared to the other mystics.

Keywords: poetical mysticism, pragmatic mysticism, subjectivist, Song of Songs, action-oriented, subjectivist.

\section{Poetical Mysticism}

In this paper some of the best known work of three outstanding representatives of poetical mysticism is briefly considered. Although exemplars of speculative and systematic mysticism, for instance, also at times engage in quasipoetical prose in their formulations and sermons, they do not do so in the same highly expressive, direct and emotionally intense manner that is so typical of the type III mystic.

For this reason Richard Rolle, Henry Suso and Madame Guyon were selected as exemplars of poetical mysticism. The poetically-inclined Christian mystic is not interested in either metaphysical speculation, or in Aristotelian analyses of the nature and elements of the mystic life. Mysticism, for him or her, is from the start a deeply personal matter of the heart, of telling the story, of recounting their experiences on the mystic journey and singing the praises of the divine, rather than merely a matter of the intellect (although the latter is not absent, of course).

\subsection{Richard Rolle (circa 1290 - 1349)}

Richard Rolle is regarded as a leading figure of fourteenth century English mysticism. He was a very passionate, poetical type of mystic who concentrated on: "...the physical manifestations of mystical graces, especially the triad of 'heat, song, and sweetness'" (McGinn, 2006: 341).

Already in the prologue to his famous work, The Fire of Love, his focus on the mystical experience and his passion clearly shows, when he states that: "More have I marvelled than I showed when, forsooth, I first felt my heart wax warm, truly, and not in imagination, but as if it were burned with sensible fire. I was forsooth amazed as the burning in my soul burst up..." (Rolle, 1920: 49). Rolle's expressive prose reflects the mental (and physical) state of the truly intense mystical exemplar in the subjectivist-empiricist (type III) mode of being.

By way of brief introductory sampler, in chapter fourteen of the Fire of Love he vividly describes his thoughts in the following manner: "...I call it 'heat' when the mind is truly set afire by eternal love, and the heart in the same manner feels itself now burning with love, not by a guess but in reality. A heart that is transformed in fire will have a feeling of fiery love. I call it 'song' when, as the fire grows great, the soul now receives the sweetness of eternal praise and thinking is turned into singing and the mind lingers in its honeyed melody." (McGinn, 2006: 342, 343).

Music played an important role in the mystical life of Rolle and in his writings, and it is reported that he took the nightingale as his model: "For him the life of contemplation was essentially a musical state, and song, rightly understood, embraced every aspect of the soul's communion with Reality." (Rolle, 1920: 3). A leading scholar of mysticism in the early 
decades of the $20^{\text {th }}$ century, Evelyn Underhill, offers her conclusion about Rolle as follows: "Here we find, fused together, the highest flights of mystical passion for the Ineffable God, and the intense devotion to the Person of Christ..." (Rolle, 1920: 9).

Rolle indicates that he favours love of God (Jesus Christ) rather than intellectual accounts of and knowledge about God. In the prologue he expresses it as follows: "...I have striven to be only in the sight of my Saviour and to dwell in full inward burning. Wherefore I offer this book to be seen: not to philosophers nor wise men of this world, nor to great divines lapped in infinite questions, but unto the ignorant and untaught...And since I here stir all manner of folk to love, and am busy to show the hottest and supernatural desire of love, this book shall bear the name: 'Burning of Love."' (Rolle, 1920: 50).

By way of a sketch of Rolle's approach, Figure 1 indicates some of the themes he discusses in Fire of Love.

Figure 1: Some themes in the Fire of Love (Rolle, 1920)

\begin{tabular}{l}
\hline 1. The difference between God's lovers and the world's (Bk. I, Ch. IV). \\
\hline 2. That the perfect lover of God had rather run into great pain than by sin that once grieve God, and why \\
God torments the righteous by the wicked (Bk. I, Ch. VIII). \\
\hline 3. The burning of love purges vices and sins; and the tokens of true friendship (Bk. I, Ch. XXII). \\
\hline $\begin{array}{l}\text { 4. Of the felicity and sweetness of God's love; and of the nightingale's song; and prayer for perseverance } \\
\text { of true ghostly [spiritual] song that worldly lovers have not (Bk. II, Ch. XII). }\end{array}$ \\
\hline
\end{tabular}

\subsubsection{God's lovers and the world's}

"The lover of God loves god with an endless and burning love and desire, whereas the wicked loves the world only: Truly if all things that we love, we love for God, rather God in them, than them we love; and so not in them but in God we delight, whom to enjoy without end we shall be glad." (Rolle, 1920: 59).

\subsubsection{The perfect lover of God}

In this chapter Rolle emphasizes that the perfect lover of God will much rather suffer pain than sin against God: "From the great fire of love so great beauty of virtue grows in souls that a righteous man would rather choose to suffer all pain than once grieve God; although he knew he might rise by penance and afterward please God more and be holier." (Rolle, 1920: 67).

\subsubsection{The purging of vices and sins}

For Rolle the 'burning love' overcomes all sin: "The burning of love truly taken into a soul purges all vices...and plants the beauty of all virtues. It never stands with deadly sin, and if it do with venial yet nevertheless the moving and desire of love in God can be so burning that they waste all venial sins, without also thinking in deed of these same venial sins: for whilst the true lover is borne to God with strong and fervent desire, all things displease him that withdraw him from the sight of God." (Rolle, 1920: 101).

\subsubsection{The sweetness of God's love}

Here Rolle sing the praises of Jesus Christ in the following manner: "Sweeter delight I know not than in my heart to sing Thee Jesu, whom I love, a song of Thy praise. A better and more plenteous felicity I know not then to feel in mind the sweet heat of love. Of all things I hold it best to set Jesu in my heart and desire no other thing. He truly has a good beginning of love that has loving tears, with sweet longing and desire for things everlasting." (Rolle, 1920: 157).

\subsection{Henry Suso (circa $1295-1366$ )}

If Richard Rolle may be regarded as an outstanding mystical praise-singer of God, Henry Suso must surely go down in history as the self-mortifying Christian mystic, par excellence.

Although an ardent admirer and defender of Meister Eckhart, Suso's brand of mysticism is, in meta-theoretical terms, the polar opposite of the former. Whereas Eckhart (the type I mystic): “...preferred to start with God: his thought 
moved from the simple divine essence to the Trinity of Persons, especially to the Word or Logos, in which he saw the archetype of creation," (Copleston, 1963: 198). Suso's thought (type III): "...moved from the human person to the latter's dynamic union with Christ, the God-Man; and he emphasized strongly the place of the Humanity of Christ in the ascent of the soul to God." (Copleston, 1963: 198).

In his book, The life of blessed Henry Suso by himself, Suso states (in the type III mode) that it is meant for those: "...who longs after special intimacy with God..." (Knox, 1865: 8). In the prologue he makes a statement that, in a sense, encapsulates his own life as mystic: "The book also tells of a man's progress in holiness; that is, how, by avoiding things, by sufferings, and by exercises, he may break through his unmortified animal nature, and arrive at great and exalted dignity..." (Knox, 1865: 7).

Following are some informative aspects of Suso's own biography and turning to the life of the mystic:

- He describes himself as a Swabian preacher: "... whose desire was to become and to be called a Servitor of the Eternal Wisdom." (Knox, 1865: 10);

- His conversion began at the young age of eighteen;

- He always had a strong feeling of dissatisfaction with his life, looking for something: "... which could bring peace to his wild heart, and he was ill at ease amid his restless ways." (Knox, 1865: 10).

An indication of noteworthy themes in the mystic life of Henry Suso is provided in Figure 2, and briefly discussed below. He was a quite extraordinary person, a driven and intense, if not obsessive, personality who was very unforgiving with himself. The lengths to which he went in self-inflicted punishment and mortification of his flesh, all for the sake of divine approval and mystical union with God, is disconcerting to the modern mind, to put it mildly.

Figure 2: Some events in Suso's life as mystic (Knox, 1865)

\begin{tabular}{|l|}
\hline 1. Befallen by a supernatural rapture (Ch. III). \\
\hline 2. Inscribed upon his heart the gracious name of Jesus (Ch. V). \\
\hline 3. Foretaste of divine consolations (Ch. VI). \\
\hline 4. Of certain visions (Ch. VIII). \\
\hline 5. Of the chastisement of his body (Ch. XVII). \\
\hline 6. Of interior sufferings (Ch. XXIII). \\
\hline
\end{tabular}

\subsubsection{Befallen by a supernatural rapture}

Suso describes, in vividly personal detail, how he was overcome with an extraordinary mental experience, which he interpreted as being subject to a 'supernatural rapture.' It is worth stating in some length:

"...He was there alone, and he stood at the lower stalls, on the right-hand side of the choir. It was, moreover, a time at which he was more than usually crushed down by a heavy weight of sorrow. Now it came to pass, that as he stood there all desolate, and with none to help or shield him, his soul was caught up in ecstasy, whether in the body or out of the body, and he saw and heard what no tongue can tell. It was without form or mode, and yet it contained within itself the entrancing delightfulness of all forms and modes. His heart was athirst, and yet satisfied; his mind was joyous and blooming; wishes were stilled in him, and desires had departed." (Knox, 1865: 13).

He goes on to relate how the experience lasted for almost two hours and left him physically and emotionally drained, yet with a wonderful and extraordinary sense of joy and elation:

"He came to himself with a deep groan, and his body sank to the ground, in spite of him, as if he were in a faint. He cried aloud piteously, and, deeply groaning, exclaimed:-Woe is me, my God! Where was I? Where am I now? Adding:-Ah, Thou, who art my heart's good! I never can this hour pass from my heart! He went on his way in body, and no one saw, or took note of anything in him outwardly; but his soul and mind were full within of heavenly marvels." (Knox, 1865: 13).

\subsubsection{Inscribing the name of Jesus on his heart}

Suso relates how, one day in the solitude of his monastery cell and with a 'burning desire' for God, he experienced the need for some kind of love-token between God and himself. Whereupon, gripped by an overpowering feeling of devotion, he: 
"...set to work, and thrust the style into the flesh above his heart, drawing it backwards and forwards, up and down, until he had inscribed the Name of Jesus upon his heart. The blood flowed plenteously out of his flesh from the sharp stabs, and ran down over his body into his bosom; but this was so ravishing a sight to him through the ardour of his love, that he cared little for the pain." (Knox, 1865: 17).

\title{
1.2.3 The foretaste of divine consolations
}

He describes how, one day he experienced 'a foretaste of divine consolations' when he visited the chapel:

"...he heard within him something which rang so tenderly, that his whole heart was stirred by it. The voice sang in tones sweet and loud, as the morning star uprose... This strain resounded in him with such unearthly sweetness, that it filled his whole soul with gladness, and he sang with it joyously." (Knox, 1865: 19).

\subsubsection{Certain visions}

He tells of the many visions he had of 'future and hidden things' and of how 'things were in heaven, hell and purgatory.' Among the vision of many souls, '...there appeared to him the blessed Master Eckart..." (Knox, 1865: 23).

\subsubsection{Chastisement of his body}

Suso describes his fiery and restless life as youth and how he sought by way of 'many devices and great penances' to subject his body to his spirit. He therefore decided upon a course of action of what can only be described as extreme selfmortification, detailed (in part) as follows:

\begin{abstract}
"He secretly caused an under garment to be made for him; and in the under garment he had strips of leather fixed, into which a hundred and fifty brass nails, pointed and filed sharp, were driven, and the points of the nails were always turned towards the flesh...In this he used to sleep at night. Now in summer, when it was hot, and he was very tired and ill from his eserves g, or when he held the office of lecturer, he would some times, as he lay thus in bonds, and oppressed with toil, and tormented also by noxious insects, cry aloud, and give way to fretfulness, and twist round and round in agony, as a worm does when run through with a pointed needle. It often seemed to him as if he were lying upon an ant-hill from the torture caused by the insects..." (Knox, 1865: 37).
\end{abstract}

He continued the practice for sixteen years, until 'a messenger from heaven' told him that God does not require this of him anymore. Whereupon he took the garments off and threw it into a river.

\subsubsection{Interior sufferings}

He describes various mental agonies and sufferings he experienced for long periods, namely:

- "...impious imaginations against the faith. Thus, there would come into his mind the thought: - How was it possible for God to become man..." This lasted for nine years. (Knox, 1865: 55);

- "...an inordinate sadness..." which lasted for eight years. (Knox, 1865: 55);

- "...a temptation which assailed him, that it would never be well with his soul hereafter, but that he must be damned eternally, no matter how rightly he should act, or how many spiritual exercises he should practice..." This lasted for a period of ten years. (Knox, 1865: 55).

Lastly, with his A Little Book of Eternal Wisdom, Henry Suso presents a treatise in the form of a dialogue with God, in which he (Suso) puts many questions to God about things that perplex him. God is named the 'Eternal Wisdom' and Suso refers to himself as the 'Servant' in this narrative. This shows the poetical (type III) Suso in full swing. A brief extract follows:

"The Servant. - Eternal Wisdom, if my soul could only penetrate the heavenly shrine of Thy divine mysteries, I would question Thee further about love. And this would be my question: Lord, Thou hast so entirely poured out the abyss of Thy divine love in Thy Passion, that I wonder if Thou canst show any more signs of Thy love?

Eternal Wisdom. - Yes. Even as the stars of heaven are countless, so the love-tokens of My unfathomable love are uncounted.

The Servant. - Ah, sweet Love of mine! ah, tender Lord elect! how my soul languishes for Thy love! Turn Thy mild countenance towards me, outcast creature that I am; see how everything vanishes and passes away in me except only the one treasure of Thy ardent love, and therefore tell me something further of this rich and hidden treasure." (Suso, 
1910: 77).

\subsection{Madame Guyon (circa 1648 - 1717)}

Madame Guyon was regarded as a controversial figure, and condemned by the Church for her so-called 'quietist' leanings, which: "...teaches complete passivity to God's action, even to the point of not wishing to be saved..." (McGinn, 2006: 41). She was a dedicated student of the Bible, and is best known for her Commentary on the Song of Songs, of Solomon.

Examples of various commentaries and narrative-interpretive (type III) analyses she made, are shown in Figure 3 , and briefly reviewed.

Figure 3: Selected verses from the Song of Songs (Madame Guyon, 1879)

\begin{tabular}{l} 
1. The King hath brought me into his store-chambers; we will exult and be glad in thee, remembering thy \\
breasts better than wine; the upright love thee. \\
\hline 2. Behold, my beloved speaketh to me and saith: rise up, my love, my dove, my fair one, and come. \\
3. Thy lips are as a scarlet fillet; and thy speech is sweet. Thy cheeks are like a piece of pomegranate, \\
besides that which is hidden within. \\
\hline 4. I charge you, O daughters of Jerusalem, if ye find my beloved, that ye tell him that I am sick of love. \\
\hline 5. I charge you, O daughters of Jerusalem, that ye stir not up, nor awake my love, until she please. \\
\hline
\end{tabular}

\subsubsection{The store-chambers of the king}

The King hath brought me into his store-chambers; we will exult and be glad in thee, remembering thy breasts better than wine; the upright love thee.

The first part of the verse is interpreted by Guyon as follows:

- The soul is rewarded by being allowed to enter the 'divine store-chambers': "...to recompense her for a love already somewhat purified, He causes her to enter into his divine store-chambers. This is a greater grace than any she has hitherto received, for it is a transient union in the powers" (Madame Guyon, 1879: 25);

- The second part (we will exult and be glad in thee, remembering thy breasts better than wine) refers, according to Guyon, to: "...the remembrance of having preferred the Bridegroom over everything else, [which] will be the height of her joy and pleasure. She had already chosen the sweetness of his milk before the wine of the pleasures of this world; wherefore, she says, we will remember thy breasts more than wine. Here she chooses God in preference to His spiritual consolations; and the transports of grace, which she experienced while drawing the milk of His breasts." (Madame Guyon, 1879: 25);

- The third part is interpreted as follows: "She adds, the upright love Thee, to signify that the true uprightness which leads the soul to dispense with all the pleasures of earth and the enjoyments of heaven, to be lost in God, is what constitutes pure and perfect love. In truth, $\mathrm{O}$ my God, none but those who are upright in the way, can love Thee as Thou eserves to be loved!" (Madame Guyon, 1879: 25, 26).

1.3.2 The call of the beloved Behold, my beloved speaketh to me and saith: Rise up, my love, my dove, my fair one, and come.

- "God having wholly turned the soul within and brought it to its centre, after having caused it to enjoy His chaste embrace to dispose it for its spiritual marriage; He causes it to take a road to all appearance totally opposite, He brings it out of itself by the mystical death." (Madame Guyon, 1879: 41);

- "This coming forth is far other than the one before alluded to, and much farther advanced, for the first was but a leaving of natural gratifications, that she might please her Well-beloved, but this is a departure from the possession of self, that she may be possessed by God only, and that, perceiving herself no more in self, she may be found in Him alone..." (Madame Guyon, 1879: 42).

\subsubsection{Scarlet lips - sweet speech}

Thy lips are as a scarlet fillet; and thy speech is sweet. Thy cheeks are like a piece of pomegranate, besides that which is 
hidden within.

The components of this verse are interpreted by Guyon as follows:

- "The lips represent the will, which is the mouth of the soul, because it presses and kisses with affection what it loves. And as the will of this soul loves only its God, and all its affections are towards Him, the Bridegroom compares it to a scarlet fillet, thus signifying the affections reunited in a single will, which is all love and charity; the whole strength of this will being reunited in its Divine object." (Madame Guyon, 1879: 55);

- "Thy speech, he adds, is sweet; because thy heart has a language that none but I can understand; because it speaks only to Me." (Madame Guyon, 1879: 55);

- "Thy cheeks are like a piece of pomegranate, which has many seeds, all contained in a single rind; so thy thoughts are, as it were, reunited in Me alone by thy pure and perfect love; and all that I have thus described is as nothing in comparison with what is yet concealed within thy deepest centre." (Madame Guyon, 1879: 55).

\subsubsection{Sick of love}

I charge you, $O$ daughters of Jerusalem, if ye find my beloved, that ye tell him that I am sick of love.

Guyon explains this verse as follows:

- "True love has no eyes for self. This poor afflicted Spouse forgets her still bleeding wounds, she forgets her loss, she does not even refer to it; she thinks solely upon Him whom she loves, and she seeks Him with so much the more perseverance as she finds more obstacles in the way." (Madame Guyon, 1879: 71);

- "She calls upon enlightened souls and says to them, O ye, to whom my Beloved will no doubt reveal Himself, I charge you by Himself to tell Him that I am sick of love." (Madame Guyon, 1879: 71);

- "What, O fairest of women, wouldst thou not that we should tell Him of thy wounds, and relate what thou hast undergone in seeking Him? Ah no! answers the generous soul, I am abundantly overpaid for all my sufferings, since I have borne them for Him, and I prefer them to the greatest good; say but one word to my Beloved, that I am sick of love! The wound made by His love in the depths of my heart is so acute, that I am insensible to all exterior pains; yea, I can even say, that in comparison they are a delight." (Madame Guyon, 1879: 71).

\subsubsection{Awaking from sleep}

I charge you, $O$ daughters of Jerusalem, that ye stir not up, nor awake my love, until she please.

The Bridegroom's is not to be woken, because there are three types of sleep:

- "The first is in the union of the powers, in which she enjoys a sleep of a powerful ecstasy, which extends much over the senses. He then begs that she may not be awakened, because this sleep is then of use to detach the senses from the objects which they loved impurely, and thus to purify them." (Madame Guyon, 1879: 93);

- "The second is the sleep of mystical death, where she expires in the arms of love. Neither is He willing she should be disturbed in this, until she awakes of herself by the all-powerful voice of God, summoning her from the tomb of death to the spiritual resurrection." (Madame Guyon, 1879: 94);

- "The third is the slumber of repose in God, permanent, lasting; an ecstatic rest, but sweet, calm and enduring, occasioning no alteration in the senses, the soul having passed into God by her happy deliverance from self. This is a rest from which she shall never be disturbed. He would not that His beloved should be interfered with in any of their slumbers, but that they should be permitted to be at rest, for they sleep in His arms." (Madame Guyon, 1879: 94);

- "The first repose is a promised rest, of which pledges are given; the second is a rest bestowed, and the third is a rest confirmed, whereof there shall be no further interruption." (Madame Guyon, 1879: 94).

\section{Pragmatic Mysticism}

In this section the pragmatic theologies of John Tauler, the anonymously authored Cloud of Unknowing, and the work of the Spanish mystic, Miguel de Molinos are reviewed.

Their mystical writings and activities have a much stronger practical focus and action-orientation (in the subjectivist-empyrean mode), compared to other mystical theologians. 


\subsection{John Tauler (circa $1300-1361)$}

John Tauler is one of the best known medieval German theologians and an admirer of Meister Eckhart. He refers to the latter in his sermons, but his own approach differed in being much more 'grounded' and practical. This turn in mystical theology is often ascribed to the fact that Eckhart's works were declared heretical by the Church, two years after his death. Thus: "...The condemnation of Eckhart had put an end to speculation..." (Clark, 2013: 45).

Some interesting aspects of Tauler's approach, reflecting his subjectivist (type IV) inclination, are that:

- He was more drawn to mystical theology and Neo-Platonism than to the: "...logical investigations of contemporary philosophers or the purely abstract metaphysical speculations of the Schoolmen." (Copleston, 1963: 195);

- He is reported to have remarked that: "... These great masters of Paris do read vast books, and turn over the leaves with great diligence, which is a very good thing; but these [spiritually enlightened men] read the true living book, wherein all things live: they turn over the pages of the heavens and the earth, and read therein the mighty and admirable wonders of God." (Winkworth, 1905: 69);

- He is considered to be more of a preacher and reformer (typical of the type IV mode) than a theologian, and was: "...especially concerned with the reformation and deepening of the spiritual life of religious and clergy..." (Copleston, 1963: 195); "...his attention [was] more directed to the application of religious principles to real life..." (Winkworth, 1905: 69);

- His pragmatic inclination shows in his concern with the moral dimension of life, and how we should live. In this regard he is reported to have said: "...'Works of love....are more acceptable to God than lofty contemplation"' (Winkworth, 1905: 95), which may just as well serve as a credo for the action-oriented, pragmatic mind. But it should be noted that Tauler was not a social reformer as such: "...For the social elevation of mankind, here and now, he has nothing whatever to say." (Tauler, 1909: 13);

- In comparison with Eckhart (the type I mystic), Tauler is viewed as more concerned with 'exegesis': "... Eckhart sees only the goal of the mystic way: the union of the soul with God...Tauler stresses the way itself, the method by which the soul can be made ready for this great consummation..." (Clark, 2013: 45).

The rest of this section reviews some of Tauler's sermons (see Figure 4) for their meta-theoretical significance as evidence of pragmatic (type IV) mysticism.

Figure 4: Some examples of Tauler's sermons (Tauler, 1909)

\begin{tabular}{|l|}
\hline 1. Men must receive all that God gives (Sermon V). (Tauler, 1909: 43) \\
\hline 2. We must commune with God (Sermon IX). (Tauler, 1909: 59) \\
\hline 3. Man should guard over all his life (Sermon XVIII). (Tauler, 1909: 105) \\
\hline 4. How man can attain to the Purity of Heart (Sermon XXVII). (Tauler, 1909: 140) \\
\hline 5. Renewal of the outer and inner man (Sermon XXXV). (Tauler, 1909: 174) \\
\hline
\end{tabular}

\subsubsection{Receiving God's gifts}

How men must receive all that God gives, and ordains for those who truly seek him in all things, as from His Hand, and as for the best. How willingly God gives great gifts, when, in lowliness of mind, we esteem ourselves of small repute; and how all things are as nothing without God.

This sermon focuses on God as the source of all gifts for which the believer must always be grateful. But, more than that: "... we must first follow St John by dying wholly to ourselves, by resigning ourselves and all our affections to God; and by receiving all things from His hand; we must deny ourselves all pleasure in the love of created things apart from God..." (Tauler, 1909: 43).

The Christian must therefore humbly accept everything as God's will: "...Therefore he who would receive from above, must of necessity place himself beneath, in true humility. And know of a truth, that if he leave anything out, so that all is not beneath, he will have nothing and receive nothing..." (Tauler, 1909: 45).

\subsubsection{Communing with God}

How we must commune with God and commit ourselves to Him; that we may conceive God and bear Him in our spirits, souls, and bodies.... 
Tauler emphasizes that the believer should be doubly grateful for receiving life in the first place and having it redeemed again. Christians should ask themselves: "... what can we give to Thee, dear Lord Jesus, in return for all the great goodness that Thou hast shown to us? In return for my destruction of the soul Thou gavest me by creation... what can I return to Thee, dear Lord Jesus, for that Thou hast given Thy Soul for mine?" (Tauler, 1909: 59).

\subsubsection{Guarding over one's life}

How man should keep strict watch and guard over all his life and his discipline. How wonderfully God exalts those who truly wait for Him, far above all temporal things; and then, for their good, smites and humbles them with all manner of troubles and temptations, that they may be driven and helped along the safest road to everlasting Salvation.

Christians must constantly be on their guard against temptations and exercise self-discipline: "Therefore guard your windows, and watch, that he [the 'enemy'] may not undermine your house like a thief; therefore watch unceasingly with all thy strength and with a collected mind. For as soon as a man gives place to pride, and is well-pleased with himself, and becomes presumptuous and self-willed, the enemy is immediately on the spot, and robs him of his purse of good works." (Tauler, 1909: 105). And, further on: "...Men who desire to walk in this narrow path must see above all things that they plant their feet firmly in the footsteps of our Lord Jesus Christ; the firmer they stand therein, the purer will they become." (Tauler, 1909: 105).

\subsubsection{Attaining to purity of heart}

How man can attain to the purity of heart which will enable him to see God in this life, to be sensible of His Divine Inspiration, and hereafter to possess and enjoy Him forever.

Tauler here gives the following advice on how he who 'desire to pleasing unto God' should live: "... he must, before all things, examine his conscience diligently, that he may learn to cleanse it, by dying to all the vices of which he was ever guilty, either outwardly or inwardly." (Tauler, 1909: 140). follows:

He goes on to specify a number of steps (essentially Tauler's version of the mystic way) that should be taken, as

- "First, he acknowledges the greatness of his sins, which he mourns and repents. Then he begins to shun and avoid evil, and to resist sin and all that causes it; so that he may learn to die unto it, that he may be clean and no longer consent to it. After this he begins to do good, and to set his face against all wanton desires of the senses..." (Tauler, 1909: 140);

- But before man can reach purity of conscience he will have to go through mental suffering: "... He earnestly desires to drive some evil things out of his heart, and to purify it; but it is sour and hard to him. His nature can as yet scarcely bear suffering, mortification and oppression and shame, though on account of many things he is conscience-stricken and repentant, and acknowledges before God and man that he has not done right in these things." (Tauler, 1909: 141);

- Following this: "...the man begins to be more spiritually-minded, in a fruitful and virtuous life..." (Tauler, 1909: 141).

\subsubsection{Renewal of the outer and inner man}

Points to a renewal of the outer and inner man, and shows how man must deny himself and die to all to which he cleaves and is attached by nature; and how God will then make His dwelling-place in him.

This sermon, presented as a dedication to a new church, stresses the necessity of renewal of the outer as well as inner self. It is phrased as follows: "The consecration of a church means much the same as a renewal; and this renewal ought always to be taking place in the inner man. The man who truly receives it must renounce all his natural tendencies, and repress and give up all to whom he may cleave, whether friends or relations. All must be given up, whatever it may be, that comes to him naturally from without, and also all in which nature finds joy, comfort or delight, in thought, word, or deed. ... Therefore man must always seek most diligently to be master of his outer animal nature. ... when man has quite killed all earthly desires in himself, then the Eternal God makes His abode in him." (Tauler, 1909: 174).

\subsection{The Cloud of Unknowing}

This work is the product of an anonymous, late-fourteenth-century English priest and its main thrust was to serve as a 
guide (in the type IV mode) for those beginning the mystical journey: "... The work was written for a young contemplative as an advanced "how-to-do-it" book." (McGinn, 2006: 262). The emphasis is on seeking God through love, rather than knowledge (the latter being more characteristic of the objectivist mode). McGinn phrases it as follows: "The Cloud's author did not lack all appreciation of the role of reason in the preparatory stages to mystical ascent, but he weighted the balance strongly in favor of love." (McGinn, 2006: 263).

With reference to the title of his work, the author explains the nature of 'darkness' in mystical contemplation as follows: "When I speak of darkness, I mean the absence of knowledge. If you are unable to understand something or if you have forgotten it, are you not in the dark as regards this thing? You cannot see it with your mind's eye. Well, in the same way, I have not said 'cloud,' but cloud of unknowing. For it is a darkness of unknowing that lies between you and your God." (McGinn, 2006: 262).

His central concern was, as Underhill formulates it: "...the perfect and passionate setting of the will upon the Divine... Not by deliberate ascetic practices, not by refusal of the world, not by intellectual striving, but by actively loving and choosing... does the spirit of man achieve its goal." (Cloud of Unknowing, 1922: 4).

For the author of the Cloud of Unknowing it is essentially a matter of becoming one with God. Figure 5 show some examples of how it can be done.

Figure 5: Examples of how the soul can become one with God (Cloud of Unknowing, 1922)

\begin{tabular}{|l|}
\hline 1. Of four degrees of Christian men's living. (Cloud of Unknowing, 1922: 24; Ch. 1). \\
\hline 2. How a man shall have him in this work against all thoughts, and especially against all those that arise \\
of his own curiosity, of cunning, and of natural wit. (Cloud of Unknowing, 1922: 32; Ch. 7). \\
\hline 3. Of three means in which a contemplative prentice should be occupied, in reading, thinking, and \\
praying. (Cloud of Unknowing, 1922: 68; Ch. 35). \\
\hline 4. How a perfect worker shall pray, and what prayer is in itself; and if a man shall pray in words, which \\
words accord them most to the property of prayer. (Cloud of Unknowing, 1922: 72; Ch. 39) \\
\hline 5. How a soul shall dispose it on its own part, for to destroy all knowledge and feeling of its own being \\
(Cloud of Unknowing, 1922: 77; Ch. 44).
\end{tabular}

\subsubsection{Christian men's living}

\section{Of four degrees of Christian men's living}

The author proposes four types or degrees according to which the Christian inclined toward the mystical life should live: "...Common, Special, Singular, and Perfect. Three of these may be begun and ended in this life; and the fourth may by grace be begun here, but it shall ever last without end in the bliss of Heaven. And right as thou seest how they be set here in order each one after other; first Common, then Special, after Singular, and last Perfect, right so me thinketh that in the same order and in the same course our Lord hath of His great mercy called thee and led thee unto Him by the desire of thine heart." (Cloud of Unknowing, 1922: 24).

\subsubsection{Against all thoughts}

How a man shall have him in this work against all thoughts, and especially against all those that arise of his own curiosity, of cunning, and of natural wit.

The author's advice in this regard is as follows: "And if any thought rise and will press continually above thee betwixt thee and that darkness, and ask thee saying, "What seekest thou, and what wouldest thou have?" say thou, that it is God that thou wouldest have. "Him I covet, Him I seek, and nought but Him." (Cloud of Unknowing, 1922: 32).

\subsubsection{Means of contemplation}

Three means in which a contemplative should be occupied, in reading, thinking, and praying.

Three means of contemplation are identified. These are: "...Reading, Thinking, and Praying. ...these three be so coupled together, that unto them that be beginners and profiteers - but not to them that be perfect, yea, as it may be here - thinking may not goodly be gotten, without reading or hearing coming before." (Cloud of Unknowing, 1922: 68). 


\subsubsection{How to pray}

How a perfect worker shall pray, and what prayer is in itself; and if a man shall pray in words, which words accord them most to the property of prayer.

These three aspects of how one should pray are expressed by the author of Cloud as follows:

- "...to pray in the height and the deepness, the length and the breadth of our spirit. And that not in many words, but in a little word of one syllable." (Cloud of Unknowing, 1922: 72);

- "Prayer in itself properly is not else, but a devout intent direct unto God, for getting of good and removing of evil." (Cloud of Unknowing, 1922: 72);

- "...when we will intentively pray for removing of evil either say, or think, or mean, nought else nor no more words, but this little word "sin." And if we will intentively pray for getting of good, let us cry, either with word or with thought or with desire, nought else nor no more words, but this word "God." (Cloud of Unknowing, 1922: 72).

\subsubsection{Knowledge and feeling}

How a soul shall dispose it on its own part, for to destroy all knowledge and feeling of its own being.

The author responds to the question of how a 'naked knowledge and feeling of thine own being,' which leads to a deep sorrow, may be overcome, as follows: "...thou shalt be wary in the time of this sorrow, that thou neither too rudely strain thy body nor thy spirit, but sit full still, as it were in a sleeping device..." (Cloud of Unknowing, 1922: 77).

\subsection{Miguel de Molinos (circa 1628 - 1697)}

Miguel de Molinos was a Spanish priest who became a controversial but 'noted confessor and spiritual director' in Rome. (McGinn, 2006: 144). He achieved fame with his The Spiritual Guide (1688), but, unfortunately for him, this work aroused opposition in ecclesiastical circles, and eventually led to his arrest and incarceration by the Inquisition.

In the introduction to The Spiritual Guide, (a clear example of the type IV mode of thought) De Molinos describes the nature and aim of the work as follows:

- "This science is not theoretical, but practical, wherein experience surpasses the most refined and ingenious speculation..." (De Molinos, 1688: 6);

- "...the doctrine of this book instructs not all sorts of persons, but those only who have the senses and passions well mortified, who have already advanced and made progress in prayer, and are called by God to the inward way..." (De Molinos, 1688: 6);

- "It hath been my first scope then, not to ascertain the inward way but to disentangle and unpester it; my next hath been to instruct the spiritual divertors, that they may not stop those souls in their course which are called by these secret paths to internal peace and supreme felicity." (De Molinos, 1688: 7);

- "The burden of this book [consists] in rooting out the rebellion of our own will, [so] that we may attain to internal peace." (De Molinos, 1688: 8).

A few examples of De Molinos' approach in The Spiritual Guide is listed in Figure 6 and briefly described below.

Figure 6: Examples from The Spiritual Guide (De Molinos, 1688)

1. To the end God may rest in the soul, the heart is always to be kept peaceable in whatsoever disquiet, temptation and tribulation. (De Molinos, 1688: 15; Bk. 1, Ch. 1).

2. Light, experience, and a divine call, are necessary for guiding souls in the inward way. (De Molinos, 1688: 44; Bk. 2, Ch. 5).

3. Instructions and counsels to confessors and spiritual directors. (De Molinos, 1688: 44; Bk. 2, Ch. 6).

4. The means of obtaining peace internal is not the delight of sense nor spiritual consolation, but the denying of self-love. (De Molinos, 1688: 65; Bk. 3, Ch. 3).

5. Inward mortification and perfect resignation are necessary for obtaining internal peace. (De Molinos, 1688: 72; Bk. 3, Ch. 7).

\subsubsection{Keeping a peaceable heart}

To the end God may rest in the soul, the heart is always to be kept peaceable in whatsoever disquiet, temptation and tribulation. 
De Molinos' advice is as follows:

- "That therefore, to the end the sovereign King may rest on that throne of thy soul, thou ought to take pains to keep it clean, quiet, void and peaceable; clean from guilt and defects; quiet from fears; void of affections, desires, and thoughts; and peaceable in temptations and tribulations." (De Molinos, 1688: 15);

- "Thou ought always then to keep thine heart in peace; that thou may keep pure that Temple of God, and with a right and pure intention, thou art to work, pray, obey and suffer, without being in the least moved, whatever it pleases the Lord to send unto thee." (De Molinos, 1688: 15);

- "It ought to be thy chief and continual exercise, to pacify that throne of thy heart that the Supreme King may rest therein. The way to pacify it will be to enter into thy self by means of internal recollection; all thy protection is to be prayer and a loving recollection in the Divine Presence. When thou seest thy self more sharply assaulted, retreat into that region of peace..." (De Molinos, 1688: 15).

\subsubsection{Guidance for the inward way}

Light, experience, and a Divine call, are necessary for guiding souls in the inward way.

"Howsoever evident it may be to thee, that thy Soul is endowed with internal light and experience; the best thing still that thou canst do, is to keep quiet and resigned in thine own nothingness, until God call thee for the good of souls..." (De Molinos, 1688: 45).

\subsubsection{Counsels to spiritual directors}

Molinos provides the following instructions and advice to spiritual directors:

- "The confessor is to make use of the name of daughter, as little as he can; because it is most dangerous, God being so jealous, and the epithet so amorous." (De Molinos, 1688: 46);

- "The employments which a confessor accepts of, out of his confession seat, ought to be but few; because God will not have him to be an agent in business; and if it were possible, he should not be seen, but in his confession chair." (De Molinos, 1688: 46);

- "A God-father, or executor to a man's last will and testament, he ought not, so much as once, to be, all his life long, because it brings many disturbances to the soul..." (De Molinos, 1688: 46);

- "The confessor or spiritual director never ought to visit his spiritual daughters, not so much as in case of sickness, unless he should indeed be then sent for, on the part of her that is ill." (De Molinos, 1688: 46);

- "If the confessor procures an inward and outward recollection, his words will be (though he knows it not) like coals kindled, setting their souls afire." (De Molinos, 1688: 46);

- "In the confessionary, his reproofs must be ordinarily gentle and sweet, although in the pulpit they are severe and rigorous..." (De Molinos, 1688: 46);

- "The Confessor ought to avoid himself, and persuade the souls under his conduct, also, to avoid all sort of outwardness, because it is much abhorred by the Lord." (De Molinos, 1688: 47).

\subsubsection{Denying self-love}

The means of obtaining peace internal is not the delight of sense nor spiritual consolation, but the denying of self-love.

The means of self-denial are stipulated as follows: "To deny ones self in all things, to be subject to another's judgment, to mortify continually all inward passions, to annihilate ones self in all respects, to follow always that which is contrary to ones own will, appetite and judgment, are things that few can do: many are those that teach them, but few are they that practice them..." (De Molinos, 1688: 66).

\subsubsection{Obtaining internal peace}

Inward mortification and perfect resignation are necessary for obtaining internal peace.

Some of the steps that De Molinos specify are as follows:

- "Resign and deny thy self wholly; for though true self-denial is harsh at the beginning, it is easy in the middle and becomes most sweet in the end." (De Molinos, 1688: 72);

- "Know that pure, perfect and essential love consists in the Cross, in self-denial and resignation, in perfect 
humility, in poverty of spirit, and in a mean opinion of thy self." (De Molinos, 1688: 72);

- "In the time of strong temptation, desertion and desolation, it is necessary for thee to get close into thy center, that thou may only look at and contemplate God, who keeps his throne and his abode in the bottom of thy Soul." (De Molinos, 1688: 72).

\section{Summary: Poetical Mysticism and Pragmatic Mysticism}

All three mystics dealt with in section 1 are cast in the same mould, meta-theoretically speaking (though Madame Guyon uses a descriptive-interpretive approach as well). They all have a strong attachment to and view Jesus Christ in a highly personal and humanistic manner. They are not mystics of the impersonal, philosophical, kind that describes God as the 'Super-essential,' 'Super-good,' 'Being,' or 'Divine substance,' as evidenced in the writings of Gregory of Nyssa, Eckhart and the Pseudo-Dionysius. All three have a strong poetical (type III) inclination and competence, using language that is highly expressive, intense and emotional, in their various dialogues and 'conversations' with God.

Section 2 reviewed the work of three mystical theologians operating in the pragmatic tradition of thought. Tauler aimed to educate and reform congregations, and especially the clergy, on how to be true Christians. His sermons reflect his practical (type IV) orientation, preaching for example, on how: 'We must commune with God' and on 'the renewal of the inner and outer man.'

Similarly, the Cloud of Unknowing is primarily addressed to novice mystics and with demonstrating to them 'how the soul can become one with God.' Miguel de Molinos' Spiritual Guide, in turn, provides (in a popularizing fashion) detailed advice on how to live the life of a mystic.

\section{General Conclusion}

It is believed that the discussion in the three separate papers (designated as: Part I, Part II and Part III) provides sufficient evidence of four distinguishable, archetypal approaches or orientations in the field of Christian mysticism. It provides a new perspective on the nature of Christian mysticism, from a meta-theoretical point of view.

\section{References}

Anonymous (1922) The cloud of unknowing, edited from the British Museum MS. Harl. 674, with an Introduction by Evelyn Underhill, London: John M. Watkins.

Clark, J. M. (2013) The great German mystics: Eckhart, Tauler and Suso, New York: Dover Publications Inc.

Copleston, F. (1963) A History of Philosophy, Volume III: Late Medieval and Renaissance Philosophy, New York: Doubleday.

De Molinos, Miguel (1688) The spiritual guide, Translated from the Italian Copy, Printed at Venice, 1685. London, 1688

Knox, T. F. (1865) The life of blessed Henry Suso by himself, London: Robson \& Son.

Madame Guyon (1879) The song of songs of Solomon, Translated from the French by J. W. Metcalf, New York: A. W. Dennett.

McGinn, B. (Ed) (2006) The essential writings of Christian mysticism, New York: The Modern Library.

Rolle, Richard (1920) The fire of love or melody of love and the mending of life or the rule of living, Translated by Richard Misyn, London: Methuen.

Suso, H. (1910) A little book of eternal wisdom, London: Burns, Oates, \& Washbourne Ltd.

Tauler (1909) The inner way: being thirty-six sermons for festivals, Translated by Hutton, A. W. London: Methuen.

Winkworth S. (1905) The history and life of the reverend doctor John Tauler with twenty five of his sermons, London: Allenson. 